\title{
Monoclonal Antibody COL-1
}

National Cancer Institute

\section{Source}

National Cancer Institute. Monoclonal Antibody COL-1. NCI Thesaurus. Code C28893.

A recombinant immunog lobulin antibody directed against the tumor-associated antigen carcinoembryonic antigen (CEA). CEA is a cell surface glycoprotein expressed at high levels in embryonic and fetal digestive epithelial tissue, breast carcinoma, and squamous cell carcinoma of the head and neck. Except for some reactivity to skin and gastric and colon mucosa, monoclonal antibody COL-1COL-1 does not appear to react with normal tissues. ( $\mathrm{NCl04)}$ 